\title{
Feasibility of Reusable Glass Bottles in Bottled Water Small Industry (Case Study: Academic Enterprise Unit of Bogor Agricultural University)
}

\author{
Tajuddin Bantacut* \\ Department of Agroindustrial Technology-Bogor Agricultural University \\ Kampus IPB Darmaga, Bogor - Indonesia \\ Adisti Kusumawati \\ Department of Agroindustrial Technology-Bogor Agricultural University \\ Kampus IPB Darmaga, Bogor - Indonesia
}

\begin{abstract}
Increasing demand for bottled drinking water (BDW) has led to an increase in the number of industries which has resulted in an increase in the amount of packaging wastes that pollute the environment. Therefore, efforts to minimize waste need to be carried out, one of them is the use of reusable glass bottles (RGB) that involve packaging returns to producers (reverse logistics). Feasibility analysis covered market, technical and management, environment, and financial aspects of the products is required before RGB is applied. Analysis of Customer Satisfaction Index (CSI) and Importance Performance Analysis (IPA) on market aspects showed that consumers are very satisfied with the quality of service, but there are several attributes that need to be improved. Conjoin analysis showed the consumers like BDW RGB products of prices less than Rp 5,000, volume $600 \mathrm{ml}$, collector empty bottles are agents, and fines are not applied. Analysis of technical and management aspects showed that it is feasible. The impact on using RGB to the environment is smaller than PET (plastic bottle). Judging from the financial criteria for internal rate of return (IRR), Net Present Value (NPV), Net Benefit Cost ratio $(\mathrm{B} / \mathrm{C})$, and Payback Period $(\mathrm{PBP})$, the use of $\mathrm{RGB}$ is more feasible.
\end{abstract}

Keywords: bottled drinking water, feasibility analysis, reusable glass bottles, environmental impacts

DOI: $10.7176 / \mathrm{JESD} / 10-2-04$

\section{Introduction}

\subsection{Background}

Increased demand for drinking bottled water (DBW) has led to an increase in the number of industries which has resulted in an increase in the amount of packaging waste that pollutes the environment. Therefore, efforts to decrease the wastes need to be carried out, one of them is the use of reusable glass bottles (RGB) that involve packaging returns to consumers to producers (reverse logistics). Feasibility analysis covering aspects of the market, technical and management, environment, and financial aspects of DBW products is required before RGB is applied. Analysis of Customer Satisfaction Index (CSI) and Importance Performance Analysis (IPA) on market aspects shows that consumers are very satisfied with the quality of services, but there are a number of attributes that need to be addressed by the bottled water industry.

The growth of the industry can cause resource depletion and pose a danger to the environment (Coskun et al. 2017). At present, the number of bottled water industries in Indonesia alone has reached around 700 companies, most of which are small and medium industries (Ministry of Industry 2018). Generally, the bottled water industry uses disposable plastic (PET) bottles as a product packaging. Therefore, increasing the volume of production of DBW causes the increasing amount of plastic waste. The amount of national waste reaches 65 million tons per day, amounting to 10.4 million tons or $16 \%$ of that amount is plastic waste (Hadi 2018). According to Yani et al. (2013) the increase in PET bottle waste has a negative impact on the environment because the plastic packaging materials cannot be easily decomposed in the environment.

Preventive measures needed to protect the environment and increase consumer awareness to use products that are environmentally friendly. This leads companies to reverse logistics (Coskun et al. 2017), it is an activity in the supply chain that involves controlling the movement towards products and materials from the last consumer to their place of origin. According to Rogers and Tibben-Lembke (1998) reverse logistics is a planning process, efficient implementation and control, effective cost flow from raw materials, intermediate goods, finished products, and related information on consumers to their original place for recovering value or proper disposal. This logistics involves taking back some values which will then enter a new supply chain (de Brito and Dekker 2003) include products and packaging. Packaging is reused, refurbished, reclaimed material, or recycled (Rogers and Tibben Lembke 1998).

Reverse logistics have been applied to various industrial sectors, both large and small industries. Research on the analysis of the returnable packaging and one-way packaging in the manufacturing industry is seen from 
the cost aspect (Wijaya and Yadrifil 2013; Yudi et al. 2014), as well as from all influential factors namely market, technical, environmental and financial aspects (Prakoso and Yusmira 2015) showed that the use of returnable packaging is more profitable. Research on the application for small industries by Wurjaningrum and Auliandri (2015) showed that the better ability of reverse logistics, the more it saves costs. Likewise, the research of Vishnupriya and Saravanan (2018) showed that the reverse logistics in small-scale food industries in India can cut food loss which means it can reduce waste in the environment.

Increasing public awareness of the environment and the limited availability of natural resources to produce new products, as well as the need to find alternatives for waste handling, encourage new regulations for reducing the amount and environmental impact of waste (Kleber 2006). Efforts needed to minimize the increase in the amount of plastic waste, one of them is replacing disposable plastic packaging (PET) with packaging that can be used repeatedly. Glass bottles can be used repeatedly or so-called returnable glass bottles (RGB) through a refill system. Some beverage industries have used glass bottles as packaging to include the tea beverage industry, carbonated drinks and mineral water. Glass bottles of the tea beverage industry can be refilled up to 20 times (Yani et al. 2014), while in the Gerolsteiner mineral water industry, they can be refilled as much as 25 to 30 times. The reuse needs the returned bottles of consumers to producers, known as reverse logistics. Reuse of packaging can cut production costs when viewed from an economic aspect (Kleber 2006).

This study has taken case of Bening Academic Enterprise Unit (SUA) of Bogor Agricultural University which is one of the small-scale industries that use PET bottle packaging. Bening produces bottled water and has been distributed over various places in the Bogor region. The production using PET bottles has contributed to plastic waste in Indonesia. Therefore, it is necessary to replace with returnable (RGB) packaging.

Based on the above description, it is necessary to analyze the feasibility of using RGB as a substitute for PET bottles on DBW products. The feasibility analysis was aimed to determine whether or not the application of reverse logistics is appropriate for RGB in small-scale industries. The analysis covered market, technical and management, environmental, and financial aspects.

\subsection{Problem Formulation}

The increasing number of PET bottle wastes originating from bottled water products has an impact on the environment. The replacement of PET bottle packaging with RGB can reduce the amount of plastic waste. RGB can be used repeatedly, but it requires reverse logistics to handle packaging returns as a back flow in the supply chain, goods flow from consumers back to the producer.

This study was aimed at determining the feasibility of using RGB packaging from market, technical and management, environment, and financial aspects. If each of the aspects is considered feasible, then overall project is also feasible. Conversely, if there were aspects that are not feasible, then this project cannot be implemented. Based on this description, the problem that was examined in this study: is the use of RGB on the BDW product feasible?

\subsection{Objectives}

The purpose of this study was to determine the feasibility of using RGB as a substitute for PET bottle packaging on DBW products. The steps taken to achieve this goal were to know:

a. the aspects of the market which include analysis of customer satisfaction and preferences, as well as the marketing mix.

b. the technical and management aspects of $D B W$ products.

c. the environmental aspects of using RGB packaging and PET bottles.

d. financial aspects of $R G B$ packaging and PET bottles based on project feasibility criteria.

\section{Method}

\subsection{Research Framework}

RGB is one type of packaging that can replace PET bottles because it is usable repeatedly. This is to underlay the idea of using RGB as a substitute for PET bottle packaging on DBW products. Before the idea were implemented, a feasibility analysis of the RGB usage is needed to include the aspects as shown in Figure 1. 


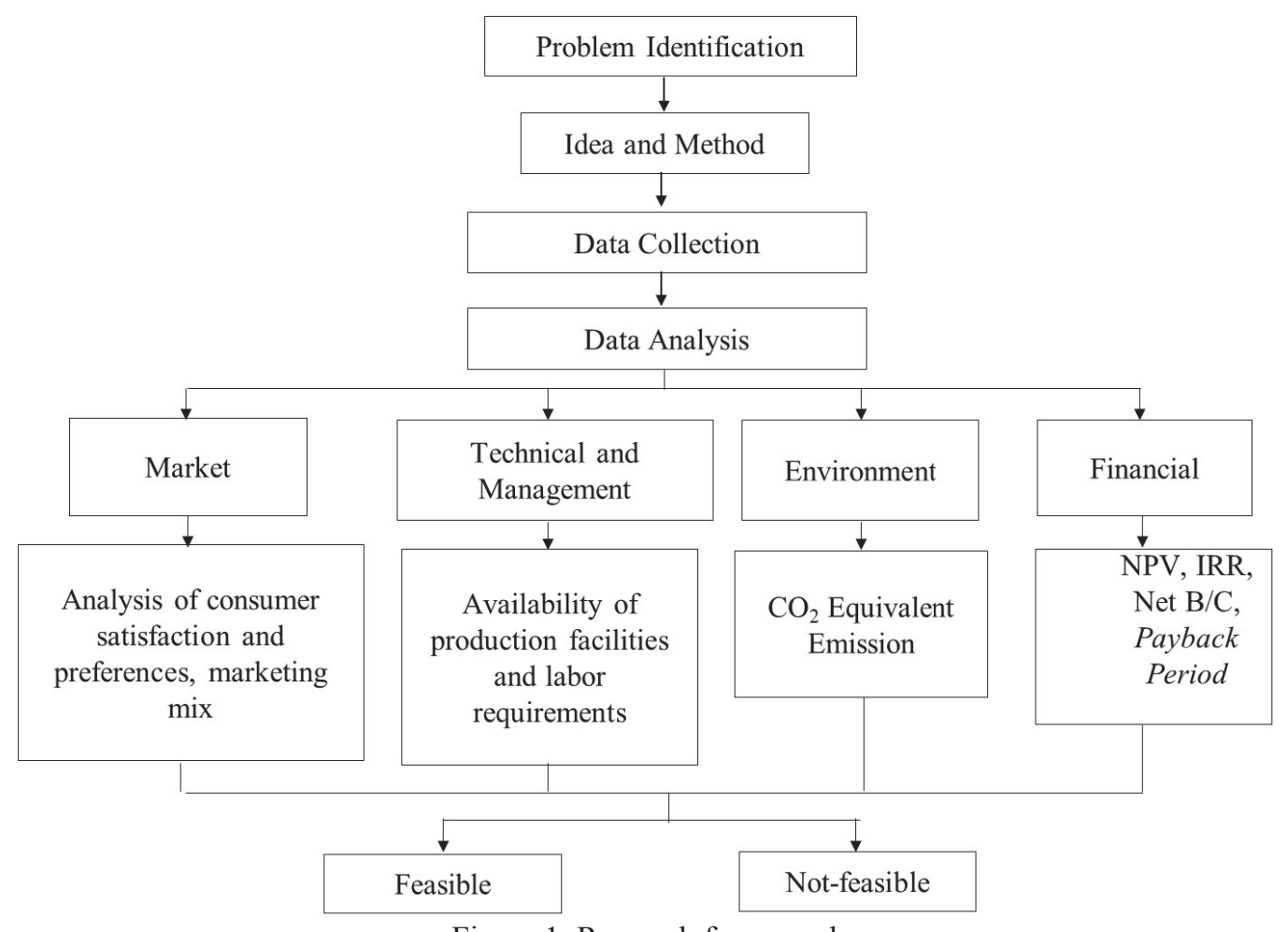

Figure 1. Research framework

\subsection{Research Procedure}

\subsubsection{Data Collection}

The data used in the study were primary and secondary data related to the case study at the Academic Enterprise Unit of Bogor Agricultural University producing BDW, called Bening, namely as follows:

a. Basic data and information about Bening such as production line, capacity, and sale.

b. Data for analysis of customer satisfaction with service quality and Bening products.

c. Data for analysis of consumer preferences for RGB packaged products.

d. Data and information regarding the specifications of machines and equipment.

e. Data on emissions generated from the production of PET bottles and RGB, as well as the use of fuel.

f. Data related to calculations in the analysis of financial aspects.

The required data is collected through literature studies, interviews with Bening stakeholders and questionnaires to consumers. Respondents for consumer preferences were selected by purposive sampling resulting in 39 respondents. Respondents for customer satisfaction are all departments and directorates within Bogor Agricultural University that consumed BDW PET supplied by Bening, totaling 11 departments.

2.2.2. Data Processing and Analysis

Data processing at each stage of the research used methods and expected outputs as in Table 1. 
Table 1. The stages, methods and expected outcomes in the study

\begin{tabular}{|c|c|c|c|c|}
\hline No & Stage & Method & Output & References \\
\hline 1 & $\begin{array}{l}\text { Analysis of customer } \\
\text { satisfaction with service } \\
\text { quality and DBW } \\
\text { Bening products }\end{array}$ & CSI and IPA & $\begin{array}{l}\text { The level of customer } \\
\text { satisfaction and } \\
\text { attributes improvement } \\
\text { priority }\end{array}$ & $\begin{array}{l}\text { Dachyar and Noviannei (2012); } \\
\text { Ayuni et al. (2017); Novarianto } \\
\text { (2014); Wong et al. (2011); Farida } \\
\text { (2011); Siyamto (2017) }\end{array}$ \\
\hline 2 & $\begin{array}{l}\text { Analysis of consumer } \\
\text { preferences for DBW } \\
\text { RGB products }\end{array}$ & $\begin{array}{l}\text { Conjoin } \\
\text { analysis }\end{array}$ & $\begin{array}{l}\text { Product characteristics } \\
\text { desired by consumers }\end{array}$ & $\begin{array}{l}\text { Bridges et al. (2011); Adiyoga dan } \\
\text { Nurmalinda (2012); Wijayanto } \\
\text { and Anggraeni (2007): Malhotra } \\
(2004)\end{array}$ \\
\hline 3 & $\begin{array}{l}\text { Determination of } \\
\text { marketing mix }\end{array}$ & Descriptive & $\begin{array}{l}\text { The marketing mix } \\
\text { consists of Product, } \\
\text { Price, Promotion, Place }\end{array}$ & $\begin{array}{l}\text { Selang (2013); Kotler and } \\
\text { Armstrong (2008) }\end{array}$ \\
\hline 4 & $\begin{array}{l}\text { Technical and } \\
\text { management analysis }\end{array}$ & Descriptive & $\begin{array}{l}\text { Availability of } \\
\text { production facilities } \\
\text { and labor requirements }\end{array}$ & Author judgement \\
\hline 5 & Environmental analysis & Descriptive & $\begin{array}{l}\mathrm{CO}_{2} \text { equivalent } \\
\text { emissions of } \mathrm{RGB} \text { and } \\
\text { PET bottles }\end{array}$ & $\begin{array}{l}\text { KLH (2012); IPCC (2006); IPCC } \\
(2007)\end{array}$ \\
\hline 6 & Financial analysis & $\begin{array}{l}\text { NPV, IRR, Net } \\
\text { B/C, PBP }\end{array}$ & $\begin{array}{l}\text { Investment eligibility } \\
\text { criteria }\end{array}$ & $\begin{array}{l}\text { Alotaibi et al. (2016); Rangel et } \\
\text { al. (2016); Rukmana and Muslim } \\
\text { (2016); El-Tahir and El-Otaibi } \\
\text { (2014); Al-Ani (2015); Rachadian } \\
\text { et al. (2013) }\end{array}$ \\
\hline
\end{tabular}

\section{Results and Discussions}

\subsection{General Information about Bening}

Bening is the academic enterprise unit that serves as a teaching industry of the Department of Agroindustrial Technolgy - Bogor Agricultural University. It produces DBW in two types of packaging, which are $19 \mathrm{~L}$ gallons and $330 \mathrm{ml}$ PET bottles. The raw water holding capacity owned is 5,000 L to support the production of 150 gallons and 15 boxes per day with carton capacity of 24 PET bottles per box. At present, Bening has distributed its products of various regions in Bogor and several agencies such as departments and offices on the Campus of Bogor Agricultural University. Bening is located inside the Campus Building of Faculty of Agricultural Technology, with area of $144 \mathrm{~m}^{2}$.

\subsection{Market Analysis}

Analysis of market aspects included consumer satisfaction and preferences, as well as determining the marketing mix.

3.2.1. Consumer Satisfaction Analysis

Customer satisfaction analysis was conducted to determine the level of customer satisfaction with service quality and DBW Bening product of PET bottles.

Customer Satisfaction Index (CSI)

The Customer Satisfaction Index (CSI) is used to determine customer satisfaction and as a reference for determining future goals. CSI can also be used to set goals in increasing customer satisfaction. The results of CSI calculations can be seen in Table 2. The CSI value of service quality of BWD Bening is $76 \%$, in the range of $75 \%-100 \%$, which means "very satisfied". This showed that consumers feel was very satisfied with the performance of service attributes of BWD Bening. However, there were still as many as $24 \%$ of customer satisfaction that has not been fulfilled, so it still needs to improve the performance of the attributes that have not met consumer expectations. 
Table 2. Customer Satisfaction Index (CSI)

\begin{tabular}{|c|c|c|c|c|c|}
\hline $\begin{array}{l}\mathrm{N} \\
\mathrm{o}\end{array}$ & Attributes & $\mathrm{MIS}_{\mathrm{i}}$ & $\mathrm{MSS}_{\mathrm{i}}$ & $\begin{array}{l}\text { Weight } \\
\text { ed } \\
\text { Factor } \\
\text { (WF) }\end{array}$ & $\begin{array}{l}\text { Weight } \\
\text { ed } \\
\text { Score } \\
\text { (WS) }\end{array}$ \\
\hline 1 & Accuracy of product delivery schedule & 3.818 & 2.818 & 0.105 & 0.297 \\
\hline 2 & $\begin{array}{l}\text { Conformity between product delivery and demand, both the } \\
\text { quantity and the quality }\end{array}$ & 3.727 & 2.909 & 0.103 & 0.299 \\
\hline 3 & $\begin{array}{l}\text { Speed and readiness of employees in providing services for } \\
\text { customers }\end{array}$ & 3.727 & 3.091 & 0.103 & 0.318 \\
\hline 4 & Speed in responding to customer complaints and problems & 3.727 & 3.000 & 0.103 & 0.308 \\
\hline 5 & $\begin{array}{l}\text { The expertise and knowledge of employees regarding products } \\
\text { can be relied upon }\end{array}$ & 3.455 & 3.000 & 0.095 & 0.286 \\
\hline 6 & $\begin{array}{l}\text { Employees always maintain professionalism in interacting with } \\
\text { customers }\end{array}$ & 3.818 & 3.273 & 0.105 & 0.344 \\
\hline 7 & Product guarantee (halal, hygienic and safe for consumption) & 3.909 & 3.182 & 0.108 & 0.343 \\
\hline 8 & Affordable product prices & 3.545 & 3.182 & 0.098 & 0,311 \\
\hline 9 & Prices offered are in accordance with the quality of the product & 3.636 & 3.091 & 0.100 & 0,310 \\
\hline 10 & Advertising / promotion media selection & 2.909 & 2.636 & 0.080 & 0,211 \\
\hline & Total & 36.273 & 30.182 & 1.000 & \multirow{3}{*}{$\frac{3.027}{76 \%}$} \\
\hline \multicolumn{5}{|c|}{ Weight Average Total (WAT) } & \\
\hline \multicolumn{5}{|c|}{ CSI } & \\
\hline
\end{tabular}

Notes: $\mathrm{MIS}_{\mathrm{i}}=$ Mean Importance Score; $\mathrm{MSS}_{\mathrm{i}}=$ Mean Satisfaction Score

Importance Performance Analysis (IPA)

Importance Performance Analysis (IPA) is a consumer satisfaction analysis method used to determine the priority to improve the attributes that affect customer satisfaction. Consumers who buy DBW Bening products have hope for the quality of services provided and for the products themselves to meet their needs. Fulfillment of expectations from consumers will lead to satisfaction. Assessment of the importance of quality of service is based on how important an attribute is to consumers. Assessment of the level of performance of service quality and product is based on the actual implementation provided by Bening in accordance with consumers response. The level of suitability between the level of performance and the level of importance of the 10 service quality attributes of DBW Bening are shown in Table 3.

The attributes that were considered the most important by Bening consumers are product guarantees (halal, hygienic and safe for consumption), with an average value of 3.909. This means consumers were most concerned with and prioritize the safety of products consumed. Therefore, Bening needs to pay attention to the quality of its products in terms of halal, cleanliness and safety of products for consumption. Attributes with the lowest average value of importance, which was equal to 2.909 , considered less important by consumers were attributes of the selection of advertising/promotional media used. These attributes were considered less important by consumers because generally Bening consumers knew of the existence of these products by word of mouth, so according to them the media advertising/promotion was not very important. 
Table 3. Level of conformity between performance level and importance assessment

\begin{tabular}{|c|c|c|c|c|}
\hline No & Attribute & $\begin{array}{l}\text { Performance } \\
\text { level } \\
\overline{(\bar{X})}\end{array}$ & $\begin{array}{l}\text { Importance level } \\
\qquad \overline{(\bar{Y})}\end{array}$ & $\begin{array}{l}\text { Conformity } \\
\text { level } \\
(\%)\end{array}$ \\
\hline 1 & Accuracy of product delivery schedule & 2.818 & 3.818 & 73.81 \\
\hline 2 & $\begin{array}{l}\text { Conformity between product delivery and } \\
\text { demand, both in terms of quantity and quality } \\
\text { of products }\end{array}$ & 2.909 & 3.727 & 78.05 \\
\hline 3 & $\begin{array}{l}\text { Speed and readiness of employees in providing } \\
\text { services for customers }\end{array}$ & 3.091 & 3.727 & 82.93 \\
\hline 4 & $\begin{array}{l}\text { Speed in responding to customer complaints } \\
\text { and problems }\end{array}$ & 3.000 & 3.727 & 80.49 \\
\hline 5 & $\begin{array}{l}\text { The expertise and knowledge of employees to } \\
\text { which products relied }\end{array}$ & 3.000 & 3.455 & 86.84 \\
\hline 6 & $\begin{array}{l}\text { Employees always maintain professionalism in } \\
\text { interacting with customers }\end{array}$ & 3.273 & 3.818 & 85.71 \\
\hline 7 & $\begin{array}{l}\text { Product guarantee (halal, hygienic and safe for } \\
\text { consumption) }\end{array}$ & 3.182 & 3.909 & 81.40 \\
\hline 8 & Affordable product prices & 3.182 & 3.545 & 89.74 \\
\hline 9 & $\begin{array}{l}\text { Prices offered are in accordance with the } \\
\text { quality of the product }\end{array}$ & 3.091 & 3.636 & 85.00 \\
\hline 10 & Advertising/promotion media used selection & 2.636 & 2.909 & 90.63 \\
\hline
\end{tabular}

The level of service assessment performance showed that the attributes that have the most satisfactory performance was the attribute of employees always maintaining professionalism in interacting with customers with an average value of 3.273 (Table 3 ). This showed that the service of employees to consumers was satisfying. In addition, there was attribute that has the lowest performance level, namely the selection of advertising/promotion media. The attribute has the lowest average performance value compared to other attributes, which was equal to 2.636, and it was considered to be unsatisfactory because Bening pay less attention to advertising/promotion activities.

The level of conformity aims to measure whether Bening service performance is in line with consumer expectations. If the percentage of the suitability level were in the range of $80-100 \%$, the performance of the attributes has met the expectations of consumers, but still needs to be improved again (Siyamto 2017). There were two attributes that have a level of conformity below $80 \%$, they were accuracy of the product delivery schedule, and the suitability between product delivery and demand, both in terms of quantity and product quality. This showed that the two attributes were not yet in line with consumer expectations, so there needs to be an improvement in the performance of the two attributes.

IPA measurements are translated into the Cartesian diagram. The $\mathrm{X}$ axis in the diagram shows the average value of the performance level while the $\mathrm{Y}$ axis shows the average value of interest. The two axes form a perpendicular line that divides the Cartesian diagram into four quadrants. Service quality attributes and Bening products were placed in the Cartesian diagram to see the position of these attributes based on priority. The results of the measurement of these attributes were based on the level of consumer interest and the level of Bening performance. The position of the ten service quality attributes and Bening products were grouped into four quadrants as presented in the Cartesian diagram shown in Figure 2. 


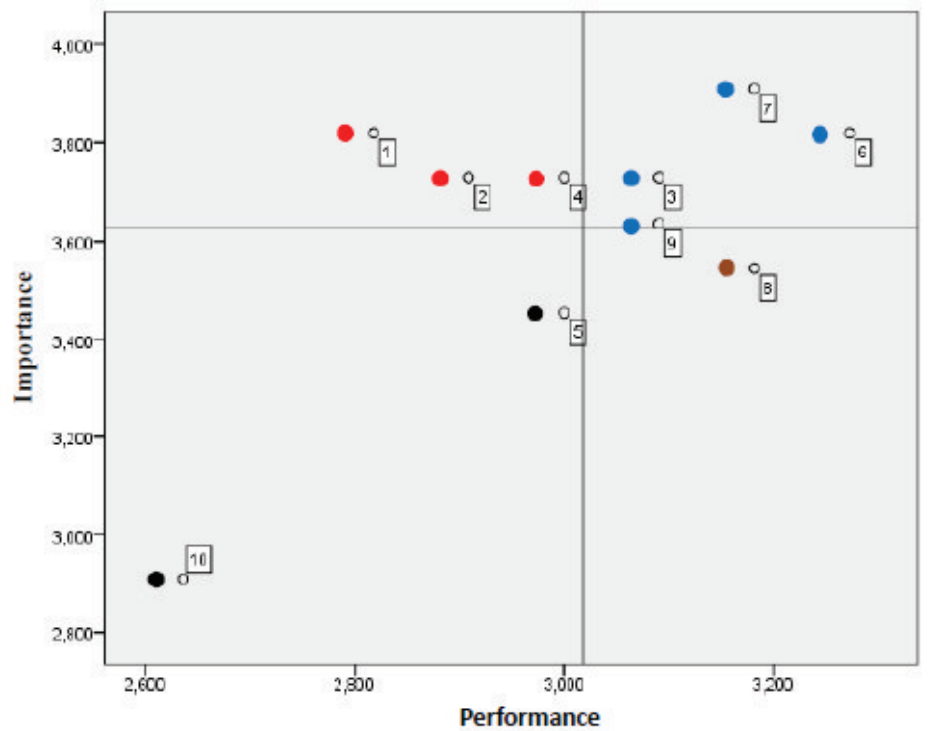

Notes:

Figure 2. Diagram of Cartesians Importance Performance Analysis

Quadrant I (Main Priority)

Attribute 1 : Accuracy of product delivery schedule.

Attribute 2 : Conformity between product delivery and demand, both in terms of quantity and quality of products.

Attribute 4 : Speed in responding to customer complaints and problems.

Attributes in this quadrant have a high level of importance, but their performance is still low or unsatisfactory for consumers. These attributes are the top priority for improving performance to improve service quality.

Quadran II (Maintain achievement)

Attribute 3 : Speed and readiness of employees in providing services for customers.

Attribute 6 : Employees always maintain professionalism in interacting with customers.

Attribute 7 : Product guarantee (halal, hygienic and safe for consumption).

Attribute 9 : Prices offered are in accordance with the quality of the product.

The attributes found in this quadrant are considered important by the customer and the company's performance is good so that the customer feels satisfied. These attributes performance is necessary to maintain.

Quadran III (Low Priority)

Attribute 5 : The expertise and knowledge of employees regarding products can be relied upon.

Attribut 10 : Advertising/promotion media selection used.

This quadrant has attributes that are considered less important by the customer and their performance is also low that they are less influential on customer satisfaction.

Quadran IV (Excessive)

Atribut 8 : Affordable product prices.

This quadrant has attributes that are considered less important by the customer, but the performance of the company is good so that the customer judges that performance is excessive. Therefore, Bening can reduce costs or resources on these attributes and allocate them to other attributes that require performance improvements.

3.2.2. Consumer Preference Analysis

Before choosing a product, everyone has their own considerations. The choices of each person about a product are called preferences. Consumer preference for DBW RGB in this study was analyzed using the Conjoin Method. This analysis aims to determine the relative importance and value of use of product attributes. Respondents rated the combinations of attributes (stimulant) that are owned by DBW RGB products, namely price, volume, empty bottle collector, and fines for agents.

Description of Preference Value

The preference value shows the level of respondents' preference for stimulation or the combination of levels of each product attribute. The highest preference is RGB DWB with $600 \mathrm{ml}$ volume, the price was less than Rp. 5,000 , empty bottles collected by the agent and a fine of Rp. 500 for each not returned bottle. Conversely,

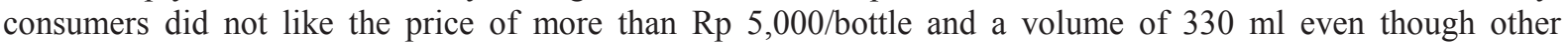
requirements were the same. 
Conjoin Analysis

Conjoin analysis provides the Value of Use Level (VUL) and Important Relative Value (IRV) of an attribute compared to other attributes used to obtain the best level combination of each attribute according to consumer preferences for DWB RGB products. Estimated multiple regression equations with dummy variables obtained from all respondents was as follow:

$\hat{\mathrm{y}}=2.370-0.413 \mathrm{x}_{1}+0.170 \mathrm{x}_{2}-0.151 \mathrm{x}_{3}+0.125 \mathrm{x}_{4}$

The model was used to determine VUL for each attribute level and IRV for each attribute. IRV is to find out the most influential attributes in determining consumer preferences or attributes that are most considered by consumers in choosing products. VUL is to find out the most preferred level of attributes on each attribute. Table 4 shows the conjoined results of the analysis.

Table 4. Value of Use Level (VUL) and Important Relative Value (IRV)

\begin{tabular}{|c|c|c|c|c|}
\hline Attributt & Level & VUL & IRV $(\%)$ & $\begin{array}{c}\text { IRV } \\
\text { Rating }\end{array}$ \\
\hline \multirow{2}{*}{ Price $\left(x_{1}\right)$} & $<\operatorname{Rp} 5,000\left(\mathrm{x}_{11}\right)$ & 0.207 & \multirow{2}{*}{48.08} & \multirow{2}{*}{1} \\
\hline & $\operatorname{Rp} 5,000-\operatorname{Rp} 10,000\left(\mathrm{x}_{12}\right)$ & -0.207 & & \\
\hline \multirow{2}{*}{ Volume $\left(\mathrm{x}_{2}\right)$} & $330 \mathrm{ml}\left(\mathrm{x}_{21}\right)$ & -0.085 & \multirow{2}{*}{19.79} & \multirow{2}{*}{2} \\
\hline & $600 \mathrm{ml}\left(\mathrm{x}_{22}\right)$ & 0.085 & & \\
\hline \multirow{2}{*}{ Empty Bottle Collector $\left(\mathrm{x}_{3}\right)$} & Agent $\left(x_{31}\right)$ & 0.076 & \multirow{2}{*}{17.58} & \multirow{2}{*}{3} \\
\hline & Consumer $\left(\mathrm{x}_{32}\right)$ & -0.076 & & \\
\hline \multirow{2}{*}{ Fine of agent $\left(\mathrm{x}_{4}\right)$} & Rp 500/not returned bottle $\left(\mathrm{x}_{41}\right)$ & -0.063 & \multirow{2}{*}{14.55} & \multirow{2}{*}{4} \\
\hline & No fine $\left(\mathrm{x}_{42}\right)$ & 0.063 & & \\
\hline
\end{tabular}

IRV shows the level of importance of each attribute. The greater NRP of an attribute indicates that the greater the influence of this attribute in determining consumer preferences. Conversely, the lower IRV indicates that this attribute is not considered in choosing a product. Table 4 shows that the highest attribute was price $(48.08 \%)$ and volume (19.79\%). This means that these two attributes are the most important or most considered when choosing DWB RGB products.

VUL is the preference value given by respondents to each level of attributes inherent in DWB RGB products. The greater the VUL of an attribute level indicates that the level is relatively preferred over other levels in an attribute. Product prices of less than Rp. 5,000 were preferred than the more expensive prices of products. Respondents preferred products of a volume of $600 \mathrm{ml}$ compared to a volume of $330 \mathrm{ml}$. Respondents preferred agents to collect empty bottles rather than consumers and did not apply fines to not returned bottles.

VUL is used to calculate the Total Use Value (TUV) which each calculated value of attribute using basic model of conjoin follows:

$\mathrm{U}(\mathrm{X})=0.207 \mathrm{x}_{11}-0.207 \mathrm{x}_{12}-0.085 \mathrm{x}_{21}+0.085 \mathrm{x}_{22}+0.076 \mathrm{x}_{31}-0.076 \mathrm{x}_{32}-0.063 \mathrm{x}_{41}+0.063 \mathrm{x}_{42}$

TUV is used to find out the combination (stimulant) most liked by respondents. The biggest combination of TUV is the combination of attributes most liked by respondents as a whole. This analysis confirmed that the desired price and volume (TUV value is 0.430 ) was a price less than Rp. 5,000 and a volume of $600 \mathrm{ml}$.

Marketing Mix

The marketing mix is a tool used to reach the intended target market. Based on the analysis of consumer preferences for BDW RGB products, the product marketing mix is described in four factors (4P), namely Product, Price, Promotion, and Place.

Product: is something that is offered and can satisfy consumers wish and needs. The product offered is BDW RGB which is drinking water packaged in a $600 \mathrm{ml}$ reusable glass bottle. The glass bottles are equipped with labels that contain information on consumers. RGB is used to minimize the use of disposable PET bottles that contribute to increasing the amount of plastic waste in the environment. The production process follows the national standards.

Price: Product price is determined by considering production costs. Based on the calculation results, the selling price of the product was set at Rp. 2,830 per bottle.

Promotion: is an activity that aims to introduce products to consumers. It can be carried out, among others, by sponsoring events held at the university campus. This would be quite effective because the target of DBW Bening products is primarily to meet drinking water needs within the campus first.

Place: is a marketing channel that is related to the activity of providing or shipping products of producers to consumers. The marketing channel used by Bening is direct distribution that is sending its products directly to consumers or agents.

The use of $R G B$ as a product packaging adds to a new activity of returning packaging from consumers to producers, which is called to reverse logistics. This can be interpreted as the process of moving goods in reverse direction, returning from the consumer (end user) to the producer. Empty bottles must be returned by the 
consumer to the manufacturer for reuse. The return of empty bottles is done by the agent which is taken by the product delivery staff according to the product delivery schedule. The number of empty bottles taken must be the same as the number of new products sent.

\subsubsection{Technical Analysis and Management}

The process of processing raw water into drinking water is no different for all types of packaging. Therefore, the technical and management aspects have not changed much from the production of DBW RGB compared to PET, but need more processes and tools. Additional new tools to install are Bottle washer and Capping machine. The standard DBW RGB production process can be seen in Figure 3.

De-crater: is the initial stage in the BDW RGB packaging process. Crate that contain empty glass bottles (RGB) originating from consumers to de-crater process, which is RGB separation from the crates.

De-capper: after the bottle is separated from the crates, then a de-capper process is carried out, namely the separation of bottles and bottle caps. This process is carried out on bottles that are still closed.

Sorting: is done manually and visually by the worker. Heavy dirty bottles, hit with paint, broken, moldy/moss will be treated and those that can still be used will be cleaned manually.

Washing: bottles that pass sorting are then washed using a bottle washer machine. The washing process aims to clean bottles of dirt and microorganisms which are carried out automatically using a bottle washing machine with $100^{\circ} \mathrm{C}$ water.

Sorting: after washing bottles is sorted visually and manually by officers against bottles and bottle caps. If there is a damage to the bottle, then the bottle goes into the recycle stage, while the bottle is in good condition and clean goes into the next process.

Filling: water that has been processed then poured into bottles which have passed the washing process. The filling process is done manually in the filling room.

Capping: giving a bottle cap is done after the filling process uses a capping machine.

Sorting: this second sorting is carried out on products that have been packaged in bottles which are done visually and manually by the staff in the product storage room. If there is a foreign object, the bottle product is emptied and refilled.

Labeling: Giving labels to bottles is done manually with a heat gun (hot air) in the product storage room. The label contains the name and address of the company that produces, net volume, name or trademark.

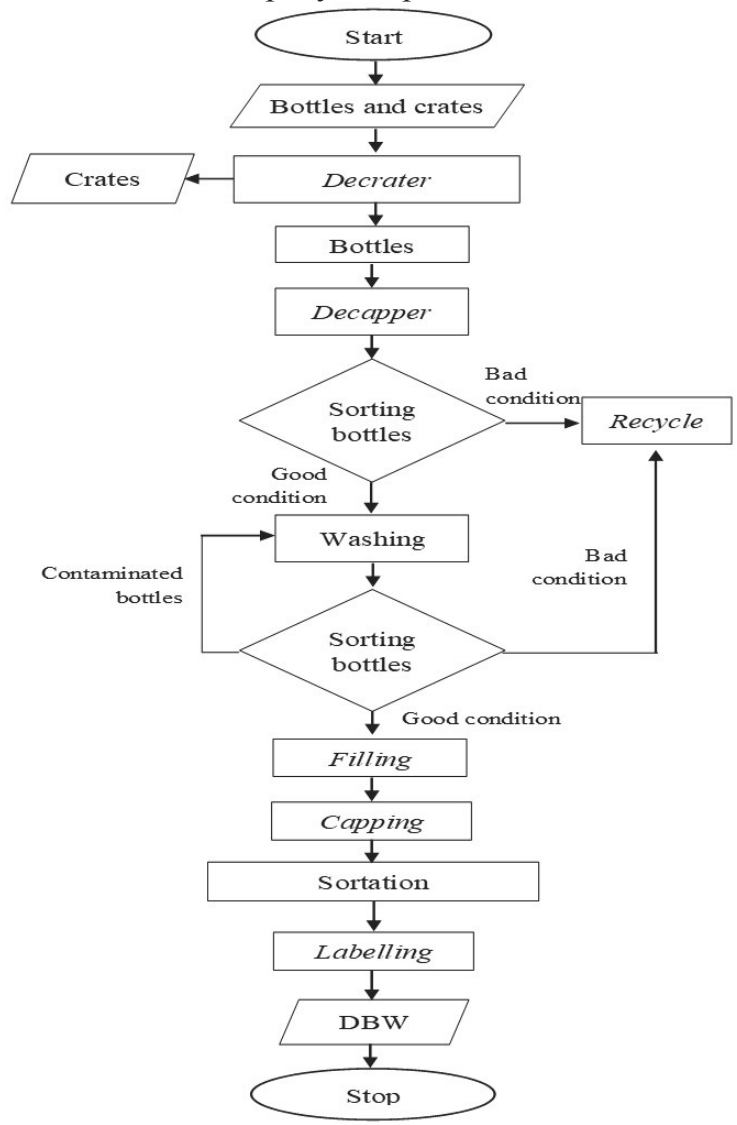

Figure 3. Packaging process DWB RGB

3.2.4. Environmental Analysis

The use of single-use bottles packaging causes an increase in the amount of PET bottles in use which will 
certainly affect the environment. The use of glass bottles (RGB) that can be reused up to 25 times are one of the efforts to cut the increasing number of PET bottle packaging waste. The need for resin raw material to make one PET bottle is $28 \mathrm{~g}$, while to make one RGB is $300 \mathrm{~g}$ of raw material in the form of silica sand. When viewed by one bottle unit, the production of RGB to require more raw material than PET bottles. Comparison between PET and RGB bottles, after considering the unreturned rate (the level of the bottle does not return) from the consumer to the producer and the bottles reused and recycled, showed that the use of RGB is expected to be more efficient in using raw materials (Yani et al. 2013).

Unreturned rate in reverse logistics activities is uncertain because the rate of return from consumers to producers is difficult to predict. Primsa (2011) conducted a study on one of the tea beverage industries that uses RGB. Trend analysis was carried out to determine the RGB return rate from the outlet to the distributor. The results showed that the more expensive the price the higher the return which can reach $95 \%$ at a price level of around Rp. 5000/bottle. This study used the RGB unreturned rate assumption of $2.3 \%$.

The number of RGB needed can be calculated by considering the number of bottle reuse ( 25 times) and empty bottle unreturn rate of consumers, using the following equation:

$$
\text { Number of bottles }=\frac{\text { Production capacity per year }}{(1 \text {-umretum rate } \mathrm{x} \text { number of reused bottles }} \text { bottles/year }
$$

RGB needs for DBW Bening production of a capacity of 187,200 bottles/year is:

$$
\text { Number of bottles }=\frac{187,200 \text { bottles/year }}{(1-0.023) \times 25 \text { times: }}=7,664 \text { bottles/year }
$$

The process of producing PET and RGB bottles need energy and raw materials. Energy is used for fuel transportation of raw materials and manufacturing (mixing, smelting, heating, cooling, and movement) (Yani et al. 2014). Energy requirements in RGB production reach about twice the energy requirements of PET bottle production, in more detail the energy and raw material requirements can be seen in Table 5 (Yani et al. 2013).

Table 5. Energy requirements and raw materials in the process of producing PET and RGB (per bottle)

\begin{tabular}{lcc}
\hline Parameter & PET & RGB \\
\hline Raw material needs $(\mathrm{g})$ & 28 & 300 \\
Total of unrenewable energy used & 4,511 & 8,256 \\
$(\mathrm{MJ})$ & 445 & 890 \\
Total of renewable energy used (MJ) & 4,956 & 9,146 \\
\hline Total energy used (MJ)
\end{tabular}

Source: as compiled by Yani et al. (2013)

Based on these data, the calculation of raw material and energy requirements was carried out according to the production capacity of Bening. In the production capacity of 187,200 bottles/year, the amount of raw material and energy needed is presented in Table 6.

Table 6. Raw material and energy needs in the production process of bottle (per year)

\begin{tabular}{lrr}
\hline \multicolumn{1}{c}{ Parameter } & \multicolumn{1}{c}{ RGB } & \multicolumn{1}{c}{ PET } \\
\hline Number of bottles & 7,664 & 187,200 \\
Raw materials (ton) & 2,299 & 5,241 \\
Total energy for producing bottles (MJ) & $70,097,490$ & $927,763,200$ \\
Raw material reuse rate (\%) & 80 & 25 \\
\hline
\end{tabular}

Reuse rate of RGB raw materials is $80 \%$, while PET is $25 \%$. This shows that RGB is more environmentally friendly because the used bottles are mostly recyclable for new RGB production, while very few PET bottles can be recycled for the production of new PET bottles.

The use of energy generates greenhouse gases (GHGs) emission that have an impact on the environment. GHGs are gases in the atmosphere that can absorb solar energy and send it back, so that the earth remains warm (Astra 2010). Emissions caused by energy are categorized as emissions from the energy sector that are $\mathrm{CO}_{2}, \mathrm{CH}_{4}$ and $\mathrm{N}_{2} \mathrm{O}$ (KLH 2012). Emissions generated from the bottle production process and transportation can be seen in Table 7.

Table 7. GHGs emission of bottle production and transportation (ton of $\mathrm{CO}_{2}$-equivalent)

\begin{tabular}{|l|r|r|r|r|r|r|}
\hline \multirow{2}{*}{ Emission } & \multicolumn{2}{|c|}{ Production } & \multicolumn{1}{c|}{ Transportation and Distribution } & \multicolumn{2}{c|}{ DBW Production } \\
\cline { 2 - 7 } & \multicolumn{1}{|c|}{ RGB } & \multicolumn{1}{c|}{ PET } & RGB & \multicolumn{1}{c|}{ PET } & \multicolumn{1}{c|}{ RGB } & \multicolumn{1}{c|}{ PET } \\
\hline $\mathrm{CO}_{2}$ & $5,194,224,029$ & $68,747,253,120$ & $4,852,786$ & $3,498,768$ & $6,646,713$ & $5,560,572$ \\
\hline $\mathrm{CH}_{4}$ & $4,416,142$ & $58,449,082$ & 47,674 & 25,022 & 14,525 & 12,151 \\
\hline $\mathrm{N}_{2} \mathrm{O}$ & $13,038,133$ & $172,563,955$ & 69,658 & 86,371 & 32,162 & 26,906 \\
\hline
\end{tabular}

The number of bottles affects the process of shipping from suppliers to producers. Shipping PET bottles certainly require more transportation than RGB because the number of PET bottles is far more than RGB. The calculation, by considering the capacity of the vehicle used to send the product, at the capacity of 187,200 bottles/year, showed that the transportation for PET bottles is 35 times while for RGB is three times. The use of 
RGB from the aspect of the DBW production processes contribute to greater GHG emissions to the environment, which means it has greater potential for global warming.

The reverse logistics activity aims to reclaim the value of unused items (de Brito and Dekker 2003) and to save production costs (Kleber 2006). The product distribution process is carried out together with taking empty bottles of the same amount as the number of products delivered. The process of the product shipping is done using a gasoline fuel vehicle. Emissions from fuel combustion in the RGB distribution process are greater than PET, because the use of fuel to the distribution process is twice as large as PET bottles. Therefore, the comparison was made of the total energy used so that RGB emissions were known to be much smaller (Table 8).

Table 8. Total $\mathrm{CO}_{2}$ equivalent (per year)

\begin{tabular}{crr}
\hline \multirow{2}{*}{$\mathrm{GHG}$} & \multicolumn{2}{c}{ Total (ton $\mathrm{CO}_{2}$ eq.) } \\
\cline { 2 - 3 } & \multicolumn{1}{c}{ RGB } & \multicolumn{1}{c}{ PET } \\
\hline $\mathrm{CO}_{2}$ & $5,205,723,528$ & $68,756,312,460$ \\
$\mathrm{CH}_{4}$ & $4,478,340$ & $58,486,255$ \\
$\mathrm{~N}_{2} \mathrm{O}$ & $13,139,953$ & $172,643,187$ \\
\hline
\end{tabular}

\subsection{Financial Analysis}

The assumptions used as the basis for financial calculations were as follows:

- The capital used comes from a bank loan.

- Project duration was 10 years and working time was 8 hours per day, 5 days per week and 260 days per year.

- The land used is land owned by the university so there was no cost for renting land.

- The type of DBW RGB sold is a volume of $600 \mathrm{ml}$.

- Interest rate used was $12 \%$.

- Annual production capacity was assumed to be the same, which was equal to 187,200 bottles.

3.3.1. Investment Cost

Investment costs consist of the cost of purchasing tools and machinery, installations, vehicles, equipment, and contingencies. The prices of the tools and machines were obtained from several suppliers that provided the industrial machinery and equipment. Installation costs consist of the cost of installing the necessary machinery and tools, and electrical installations. Equipment costs included the office supplies. Contingency costs were estimates of budget costs of unexpected additional that was assumed to be $10 \%$ of the total investment (Table 9). The DBW RGB production process requires more machines and equipment so that the investment costs incurred were greater.

Table 9. Investment cost (rupiah)

\begin{tabular}{clrr}
\hline No. & Cost component & \multicolumn{1}{c}{ RGB } & \multicolumn{1}{c}{ PET } \\
\hline 1 & Machineries and tools & $138,026,480$ & $124,832,880$ \\
2 & Equipment & $1,275,000$ & $1,275,000$ \\
3 & Installation & $75,914,564$ & $68,658,084$ \\
4 & Vehicle & $129,000,000$ & $129,000,000$ \\
5 & Contingency & $34,421,604$ & $32,376,596$ \\
\hline & Total & $378,637,648$ & $356,142,560$
\end{tabular}

\subsubsection{Production Costs and Revenue}

Production costs consist of fixed costs and variable costs. Fixed costs are a component of costs that are not influenced by the amount of production intensity while variable costs are costs that change with the volume of production. Revenue are the result of product sales. The cost of production and revenue of DBW RGB and PET bottles are in Table 10 .

Table 10. Production costs and revenue (rupiah)

\begin{tabular}{|l|c|c|}
\hline \multicolumn{1}{|c|}{ Cost Component } & RGB & Botol PET \\
\hline Production Cost & & \\
\hline Fixed cost & $183,359,579$ & $181,769,528$ \\
\hline Variable cost & $262,593,916$ & $350,345,722$ \\
\hline Total & $445,953,495$ & $532,115,250$ \\
\hline Revenue & $529,776,000$ & $621,504,000$ \\
\hline
\end{tabular}

The production cost of PET DBW was greater than RGB because it was influenced by variable costs, especially the cost of purchasing packaging. The packaging needed for the production of DBW PET was 187,200 bottles/year, according to a predetermined production capacity, while DBW RGB requires 7,664 bottles/year. Likewise, revenue from sales of PET DBW was greater than DBW RGB. This happened because the larger production costs will affect the selling price of the product.

3.3.3. Cost Benefit

The profit and loss projection were used to see profits based on the amount of income and expenditure. The 
difference between production income and expenditure is called operating profit. Operating income after tax is called net income. Based on the calculation, the net profit from the sale of DBW RGB, which was equal to Rp. $25,547,145$ is greater than DBW PET which was only Rp. 21,023,310. This is influenced by the amount of revenue and expenditure that is different between the two.

3.3.4. Investment Criteria

The investment eligibility criteria used in this study were Net Present Value (NPV), Internal Rate of Return (IRR), Net B/C, and Payback Period (PBP). The results of calculating the investment eligibility criteria from production are presented in Table 11 . The value of these criteria showed, financially, both productions were feasible to run, but RGB DWB was more profitable.

Table 11. Feasibility criteria of investment

\begin{tabular}{|l|r|r|}
\hline \multicolumn{1}{|c|}{ Criteria } & \multicolumn{1}{|c|}{ RGB } & \multicolumn{1}{c|}{ PET } \\
\hline NPV (Rp) & $29,948,812$ & $15,128,054$ \\
\hline IRR $(\%)$ & 55 & 15 \\
\hline Net B/C & 1.30 & 1.14 \\
\hline PBP (year) & 7.83 & 8.34 \\
\hline
\end{tabular}

\section{Conclusions and Recommendations}

\subsection{Conclusions}

Based on the analysis of necessary aspects that have been carried out, the proposed project was the use of $600 \mathrm{ml}$ of Returnable Glass Bottles (RGB) as a packaging of bottled water with the selling price of Rp. 2,830/bottle. The empty bottle return system is collected by the agent, which will then be taken by distribution staff together at the time of delivery of the new product.

The proposed production capacity of 720 bottles/day requires additional machines and equipment in the form of bottle washer and capping machine. The addition of labor is needed to improve the performance of service attributes in the form of accuracy of product delivery schedules, suitability between the number of shipments and requests, namely the company's ability to meet consumer demands, and speed in responding to customer complaints and problems.

The use of RGB can save energy use and cut greenhouse gas (GHG) emissions generated from the use of energy. Financially, RGB used is also more profitable because it saves production costs, especially packaging costs.

\subsection{Recommendations}

Broader market and marketing studies need to be carried out so that production and sales capacity can be increased to improve resource savings and environmental protection. Scattered small-scale water treatment needs to be compared to large-scale businesses that are centered on economic and environmental aspects.

\section{References}

Adiyoga W, Nurmalinda. 2012. Analisis konjoin preferensi konsumen terhadap atribut produk kentang, bawang merah, dan cabai merah. Jurnal Hortikultura. 22(3): 292-302.

Al-Ani MK. 2015. A strategic framework to use Payback Period in evaluating the capital budgeting in energy and oil and gas sectors in Oman. International Journal of Economics and Financial Issues. 5(2): 469-475.

Alotaibi J, Denina A, Meng F. 2016. Financial analysis of IBM. Research. 1-20.

Astra IM. 2010. Energi dan dampaknya terhadap lingkungan. Jurnal Meteorologi dan Geofisika. 11(2): 131-139.

Ayuni NWD, Adiaksa IMA, Sari IGAMKK. 2017. Analisis kepuasan pelanggan terhadap produk kopi biji salak. Jurnal Bisnis dan Kewirausahaan. 13(2): 120-126.

Bridges JFP, Hauber AB, Marshall D, Lloyd A, Prosser LA, Reiger DA, Johnson FR, Mauskopf J. 2011. Conjoint analysis applications in health-a checklist: A report of the ISPOR good research practices for conjoint analysis task force. Value in Health. 14: 403-413.

[BSN] Badan Standardisasi Nasional. 2006. SNI 01-3553-2006: Air minum dalam kemasan.

Coskun AE, Aglaogu G, Kutluk FA. 2017. Reverse logistics, its relation with cost and sustainability, its inclusion in curriculum. Journal of Educational and Instructional Studies in the World. 7(4): 96- 106.

Dachyar M, Noviannei M. 2012. Customer Sarisfaction Index telecommunication industry in Indonesia. World Academy of Science, Engineering and Technology. 1064-1066.

de Brito MP, Dekker R. 2003. A framework for reverse logistics. Erim Report Series Research in Management. 1-29.

El-Tahir Y, El-Otaibi D. 2014. Internal Rate of Return: A suggested alternative formula and its macroeconomics implications. Journal of American Science. 10(11): 216-221.

Etikan I, Musa SA, Alkassim RS. 2016. Comparison of concenience sampling and purposive sampling. American Journal of Theoretical and Applied Statistics. 5(1): 1-4. 
Farida FI. 2011. Analisis kepuasan pelanggan terhadap kualitas pelayanan jasa kereta api ekspres Pakuan Jabodetabek (Studi kasus Kereta Api Ekspres Pakuan Bogor-Jakarta. [skripsi]. Bogor (ID): IPB.

Green PE, Srinivasan V. 1978. Conjoint analysis in consumer research: issues and outlook. Journal of Consumer Research. 5: 103-123.

Hadi DW. 2018. Siaran Pers: Dorong Circular Economy melalui Pemanfaaatan Sampah Plastik Berkelanjutan. [internet]. [diakses pada 2018 Agustus 04]. Tersedia pada: http://ppid.menlhk.go.id/siaran_pers/browse/1402.

[IPCC] Intergovernmental Panel on Climate Change. 2006. Guidelines for Greenhouse Gas Inventories Volume 2 Energy. Prepared by the National Greenhouese Gas Inventories Programme, Eggleston S, Buendia L, Miwa K, Ngara T, Tanabe K. [eds]. Japan (JPN): IGES.

[IPCC] Intergovernmental Panel on Climate Change. 2007. Climate change 2007 The Physical Science Basis. Contribution of Working Group I to the Fourth Assessment Report of the Intergovernmental Panel on Climate Change, Solomon S, Qin D, Manning M, Marquis M, Averyt K, Tignor MMB, Miller HL, Chen Z. [eds]. New York (USA): Cambridge University Press.Kemenperin. 2018. Siaran Pers Kementerian Perindustrian: Jamin Keamanan, Kemenperin Atur SNI Wajib bagi Minuman Kemasan. [internet]. [diakses pada 2018 Juli 06]. Tersedia pada : http://aspadin.com/pressmedia/archives/03-2018.

Kleber R. 2006. Dynamic Inventory Management in Reverse Logistics. Berlin (DE): Springer.

[KLH] Kementrian Lingkungan Hidup. 2012. Pedoman Penyelenggaraan Inventarisasi Gas Rumah Kaca Nasional: Buku II Volume I Metodologi Penghitungan Tingkat Emisi Gas Rumah Kaca Kegiatan Pengadaan dan Penggunaan Energi. Jakarta (ID): Kementrian Lingkungan Hidup.

Kotler P, Armstrong GA. 2008. Prinsip-Prinsip Pemasaran. Jakarta (ID): Penerbit Erlangga.

Malhotra NK. 2004. Riset Pemasaran Pendekatan Terapan. Jakarta (ID): Indeks.

Novarianto A. 2014. Tingkat kepuasan dan loyalitas konsumen Waroeng Hotplate Odon Bogor, Jawa Barat. [skripsi]. Bogor (ID): IPB.

Prakoso G, Yusmira H. 2015. Analisis kelayakan penggantian pallet kayu ke returnable pallet rangka besi untuk pengiriman impor di PT. XYZ. Teknoin. 21(4): 207-224.

Primsa LY. 2011. Preliminary study on deposit refund system (DRS) on Teh Botol Sosro [tesis]. Jakarta (ID): Universitas Indonesia.

Rachadian FM, Agassi EA, Sutopo W. 2013. Analisis kelayakan investasi penambahan mesin frais baru pada CV. XYZ. Jurnal TI Undip. 8(1): 15-20.

Rangel AS, Santos JCS, Savoia JRF. 2016. Modified profitability index and internal rate of return. Journal of International Business and Economics. 4(2): 13-18.

Rogers DS, Tibben-Lembke RS. 1998. Going Backwards: Reverse Logistics Trends and Practices. Nevada: Reverse Logistics Executive Council.

Rukmana SH, Muslim MA. 2016. Sistem pendukung keputusan tender proyek menggunakan metode Benefit Cost Ratio. Jurnal Sains dan Teknologi. 5(2): 855-859.

Selang CAD. 2013. Bauran pemasaran (marketing mix) pengaruhnya terhadap loyalitas konsumen pada Fresh Mart Bahu Mall Manado. Jurnal EMBA. 1(3): 71-80.

Siyamto Y. 2017. Kualitas pelayanan bank dengan menggunakan metode Impotance Performance Analysis (IPA) dan Customer Satisfaction Index (CSI) terhadap kepuasan nasabah. Jurnal Ilmiah Ekonomi Islam. 3(1): 63-76.

Visnupriya T, Saravanan S. 2018. Reverse logistics in small scale food processing industries with practices and efficiency in India. International Journal of Innovative Research in Technology. 5(1): 415-419.

Wijaya S, Yadrifil. 2013. Analisis perbandingan investasi implementasi module 5B returnable rack (RR) packaging roundtrip terhadap module 5B 1-way Indonesia-Thailand dengan metode Total Cost Ownership (TCO) di PT Toyota Motor Manufacturing Indonesia. FT UI.

Wijayanto H, Anggraeni Y. 2007. Analisis konkoin: metode full profile dan CBC untuk menelaah persepsi mahasiswa terhadap pilihan pekerjaan. Forum Statistika dan Komputasi. 12(1): 8-17.

Wong MS, Hideki N, George P. 2011. The use of Importance-Performance Analysis (IPA) in evaluating Japan's E-government services. Journal of Theoritical and Applied Electronic Commerce Research. 6(2): 17-30.

Wurjaningrum F, Auliandri TA. 2015. Analisis anteseden reverse logistics capabilities dan penghematan biaya usaha kecil dan menengah di Surabaya dan sekitarnya. Jurnal Manajemen Teori dan Terapan. 8(3): 152162.

Yani M, Warsiki E, Wulandari N. 2013. Penilaian daur hidup botol PET (polyethylena terephtalate) pada produk minuman. Jurnal Bumi Lestari. 13(2): 307-317.

Yani M, Warsiki E, Wulandari N. 2014. Penilaian daur hidup botol gelas pada produk minuman teh . Jurnal Teknologi Industri Pertanian. 24(2): 166-178.

Yudi NAG, Anityasari M, Vanany I. 2014. Pengembangan model operasional reverse logistics penggunaan kembali kemasan sepeda. Prosiding Seminar Nasional Manajemen Teknologi XX. 